\title{
How the Current Paradigm Shift is Changing Our Understanding of Ethics
}

\author{
Chet W Sisk*
}

\section{Abstract}

In this paper I will share the evidence of a world-wide socio-spiritual paradigm shift in our basic belief systems. This shift is leading to a realignment of our ethical approach to common questions and requires a different collective approach in navigating the subject of ethics. I will also share what those different collective approaches can look like.

Keywords: Spirituality, Religion, Paradigm shift, Ethics, Adaptation, Society

\section{Introduction}

A socio-spiritual paradigm shift is popularly known today as an immediate, often dramatic change in basic assumptions in spirituality, science, economics and society. These assumptions are loosely aggregated into a tool we commonly call conventional wisdom. My contention is that a paradigm shift of unique and definitive proportion is happening now and challenging the rules that have guided human experience for hundreds of years. I believe this is the challenge of our current dilemma when it comes to discussing ethics today. Too often we are discussing ethics under the rules of a previous time (the old paradigm) at a time when only new rules should be applied. The rules that we used a few short years ago no longer have cache in a world that has transformed.

* Leadership Development Specialist for the World Assembly of Youth. chet@chetsisk.com 
It now becomes important to establish a new set of ethical "suggestions" to guide human existence in a changed world.

It is my contention that a large section of the world's population is facing personal, societal and spiritual crises because they are unaware, in denial, or resistant to the current shift. This denial of what is happening leads us to make decisions in ethics based on outdated or false information. In my book, Think this/Not that: It's time to update your conventional wisdom, I mention that most people were making decisions about their personal lives, voting for laws, supporting policy and directing their futures based on outdated, inaccurate and outright false information that have been a part of our social fabric for some time. These were the ideas of conduct promoted and exported by powerful countries that amassed wealth through the accumulation of material goods and natural resources. These countries ruled and exported their beliefs for the past 500 years or so. There is a general assumption that since those beliefs have been around for some time, somewhere along the line, someone vetted the ethical value of this information. Thus, it must be right on some level "because millions of people can't be wrong". Coming from a media background, I have an appreciation of how assumptions can take on a life of their own and basically live outside of the field of peer scrutiny. This unfortunate regular part of the 20th century has led to some of the world's greatest atrocities and formed ethical approaches that we would now consider unconscionable.

Here are some examples: (i) Slavery in the United States and throughout the New World where tens of millions of people of African descent were determined to be $3 / 5$ th of a human being, thus justifying the 250 year institution. (ii) Stalin's Purge where the former Soviet strongman starved and assassinated millions of his own people, justifying his position by saying a. he was a ruler of destiny $b$. those people were a threat to security $c$. the alleged saboteurs would disrupt everyone's way of life. (iii) Nazi Germany where millions of Jews, Roma, and other "undesirables" were put to death based on the idea of Germans being a master race and others should be put to death because of their inferiority as a way to improve the world. World War I, World War II, Pol Pot's rule, The Rape Of Nanking, etc. This list is quite extensive. 
Modern human history is written and organized around these regular occurrences. Our approach to ethics then was centered around what's being called "the tenets of the old paradigm" - a way of thinking in previous years that featured power, strength, the accumulation of material resources, fear, control of information, and propaganda. If a group could leverage these elements, they could also write the ethical position of the day. Usually that position justified what actions the ruling country was doing to accumulate wealth and power. Some of the practices supported by the ethics used in the old paradigm are so embarrassing now; some people refuse to talk about them to this day. They were considered quite ethical in their era, but today they are considered wildly outrageous and even barbaric.

Consider the practice of labelling people of African descent 3/5ths of a human being. This was an idea originally promoted by American and European slave traders to justify the practice and play into the "white man's burden" narrative - that white people had a moral and ethical duty to rule the world. Female genital mutilation is based on the idea of women being second class citizens and that this "treatment" would help women control their sexual appetites. While it is against the law in most countries, it is still being practiced in different places around the world where women are not valued in the same way men are. The idea that we are the only living beings in the universe is being dismantled as we speak as more and more planets are discovered that have the right elements for the development of carbon-based life forms. This is being furthered by regular and consistent recorded evidence of extraterrestrial visits to Earth via UFOs and Ancient Alien artifacts. The ethics just a few hundred years ago would have been considered heresy in the same way stating that the sun revolved around the earth instead of the other way around. Either statement in that time would have brought death to those who shared it. A vestige of those times ring today, where people speaking of extraterrestrial life are still met with some ridicule.

Enter the rules of engagement based on new paradigm ideas. This new way means a re-evaluation of our long held conventions and opening up to new way forward. The new paradigm features collaboration, cooperation, feminine principles, intuitive knowledge, 
connectedness and loving kindness. These elements are almost polar opposite from old paradigm ideas. However, I believe that we must articulate and advocate what the ethical approach to these new paradigms will be.

Yes, an approach will emerge organically, but I submit that the articulation of these new ethical considerations is part of the organic emergence. Allow me to share a graph that shows old paradigm approaches, their new paradigm replacement and the ethical positions for each that would be in keeping with this new way forward.

\begin{tabular}{|c|c|c|c|}
\hline $\begin{array}{c}\text { Old } \\
\text { Paradigm }\end{array}$ & Ethics & New Paradigm & Ethics \\
\hline $\begin{array}{l}\text { Human exis- } \\
\text { tence is li- } \\
\text { near. }\end{array}$ & $\begin{array}{l}\text { He who dies with } \\
\text { the most toys } \\
\text { wins. }\end{array}$ & $\begin{array}{l}\text { Human existence } \\
\text { is cyclical. }\end{array}$ & $\begin{array}{l}\text { We're connected to } \\
\text { the past and future } \\
\text { of humanity. }\end{array}$ \\
\hline $\begin{array}{l}\text { Competition } \\
\text { is the way of } \\
\text { humanity. }\end{array}$ & $\begin{array}{l}\text { Survival of the } \\
\text { fittest. }\end{array}$ & $\begin{array}{l}\text { Humanity is most } \\
\text { successful in } \\
\text { cooperative } \\
\text { models. }\end{array}$ & $\begin{array}{l}\text { Helping each other } \\
\text { ensures our spe- } \\
\text { cies' success. }\end{array}$ \\
\hline $\begin{array}{l}\text { We need a } \\
\text { leader. }\end{array}$ & $\begin{array}{l}\text { The ruler is abso- } \\
\text { lute, top down } \\
\text { and beyond re- } \\
\text { proach. }\end{array}$ & $\begin{array}{l}\text { We need leader- } \\
\text { ship }\end{array}$ & $\begin{array}{l}\text { Everyone must } \\
\text { embrace her role } \\
\text { in the leadership } \\
\text { model. }\end{array}$ \\
\hline Get the facts. & $\begin{array}{l}\text { The data won't } \\
\text { lie. }\end{array}$ & Get the meaning. & $\begin{array}{l}\text { What does this } \\
\text { mean for all par- } \\
\text { ties involved? }\end{array}$ \\
\hline $\begin{array}{l}\text { We must } \\
\text { create a plan. }\end{array}$ & $\begin{array}{l}\text { Our lives should } \\
\text { be ordered. }\end{array}$ & $\begin{array}{l}\text { We must discover } \\
\text { the purpose. }\end{array}$ & $\begin{array}{l}\text { Is this the right } \\
\text { thing to do, and to } \\
\text { what end? }\end{array}$ \\
\hline Avoid risk. & $\begin{array}{l}\text { Risk could mean } \\
\text { loss, which } \\
\text { means a possible } \\
\text { loss of what has } \\
\text { been gained. }\end{array}$ & $\begin{array}{l}\text { Create } \\
\text { opportunity. }\end{array}$ & $\begin{array}{l}\text { Opportunity could } \\
\text { mean new ideas } \\
\text { and possibilities } \\
\text { we would have } \\
\text { missed before. }\end{array}$ \\
\hline $\begin{array}{l}\text { Control the } \\
\text { information } \\
\text { flow. }\end{array}$ & $\begin{array}{l}\text { Create structures } \\
\text { that keep secrets. }\end{array}$ & $\begin{array}{l}\text { Control the } \\
\text { information flow. }\end{array}$ & $\begin{array}{l}\text { Create structures } \\
\text { that make sure } \\
\text { information is } \\
\text { available to } \\
\text { everyone. }\end{array}$ \\
\hline
\end{tabular}




\begin{tabular}{|c|c|c|c|}
\hline $\begin{array}{c}\text { Old } \\
\text { Paradigm }\end{array}$ & Ethics & New Paradigm & Ethics \\
\hline $\begin{array}{l}\text { The criminal } \\
\text { justice } \\
\text { system. }\end{array}$ & $\begin{array}{l}\text { Keep order in } \\
\text { society. }\end{array}$ & Restorative justice. & $\begin{array}{l}\text { Help restore all } \\
\text { parties when a } \\
\text { wrong occurs. }\end{array}$ \\
\hline Monitor. & $\begin{array}{l}\text { Keep your eye } \\
\text { out for threats. }\end{array}$ & Understand. & $\begin{array}{l}\text { Figure out what's } \\
\text { going on. }\end{array}$ \\
\hline $\begin{array}{l}\text { Newtonian } \\
\text { Science. }\end{array}$ & $\begin{array}{l}\text { If it can't be } \\
\text { proven through } \\
\text { the Scientific } \\
\text { Method, it } \\
\text { doesn't exist. }\end{array}$ & Quantum Science. & $\begin{array}{l}\text { There are things } \\
\text { and possibilities } \\
\text { that defy our } \\
\text { current knowledge } \\
\text { base. }\end{array}$ \\
\hline $\begin{array}{l}\text { Get the best } \\
\text { tools } \\
\text { available. }\end{array}$ & $\begin{array}{l}\text { Our technology } \\
\text { will lead the way. }\end{array}$ & $\begin{array}{l}\text { Get the right } \\
\text { people available. }\end{array}$ & $\begin{array}{l}\text { Our people will } \\
\text { lead the way. }\end{array}$ \\
\hline $\begin{array}{l}\text { Does it } \\
\text { maximize } \\
\text { profits? }\end{array}$ & $\begin{array}{l}\text { The profit motive } \\
\text { is the most } \\
\text { important thing. }\end{array}$ & Is it sustainable? & $\begin{array}{l}\text { How it affects our } \\
\text { quality of life is } \\
\text { the most } \\
\text { important thing. }\end{array}$ \\
\hline $\begin{array}{l}\text { Think outside } \\
\text { the box. }\end{array}$ & $\begin{array}{l}\text { The box is the } \\
\text { reference point } \\
\text { that we create } \\
\text { new things. }\end{array}$ & There is no box. & $\begin{array}{l}\text { We can create new } \\
\text { possibilities } \\
\text { without prior } \\
\text { references. }\end{array}$ \\
\hline $\begin{array}{l}\text { God blesses } \\
\text { those with } \\
\text { wealth. }\end{array}$ & $\begin{array}{l}\text { Accumulation of } \\
\text { material } \\
\text { resources is a } \\
\text { sign that we are } \\
\text { in God's favor. }\end{array}$ & $\begin{array}{l}\text { Blessed are the } \\
\text { meek, for they } \\
\text { shall inherit the } \\
\text { earth. }\end{array}$ & $\begin{array}{l}\text { The quality of our } \\
\text { character is the } \\
\text { new wealth. }\end{array}$ \\
\hline
\end{tabular}

These are only a few of the philosophical changes happening in the world today.

In my new book, Welcome To A Cooler World, I note that the philosophical changes happening in the world in this new paradigm that are leading us to re-evaluate many long-held ethical approaches is not based on blind optimism, but on worldwide trends. Trends don't tell the story of what we hope the future will be, but of deci- 
sions we've already made about the future. Here are some of those trends.

\begin{tabular}{|l|l|}
\hline \multicolumn{1}{|c|}{ The Trend } & \multicolumn{1}{|c|}{ The Changing Ethical Position } \\
\hline $\begin{array}{l}\text { War: There are fewer wars } \\
\text { between organized States now } \\
\text { than at any other time in } \\
\text { recorded human history. }\end{array}$ & $\begin{array}{l}\text { This has stimulated the consideration } \\
\text { of whether war is a viable means of } \\
\text { resolving conflict in an interconnected } \\
\text { world. }\end{array}$ \\
\hline $\begin{array}{l}\text { The Death Penalty: More and } \\
\text { more countries are getting rid of } \\
\text { the death penalty. }\end{array}$ & $\begin{array}{l}\text { This has charged the idea that the } \\
\text { death penalty is neither a deterrent to } \\
\text { crime nor humane. }\end{array}$ \\
\hline $\begin{array}{l}\text { IQ Tests: We are devaluing IQ } \\
\text { tests and rethinking what it } \\
\text { means to be intelligent. }\end{array}$ & $\begin{array}{l}\text { This push is causing societies to value } \\
\text { their citizens differently than using a } \\
\text { test that only measures a limited and } \\
\text { narrow band of intelligence markers. }\end{array}$ \\
\hline $\begin{array}{l}\text { Society: We are dismantling } \\
\text { Maslow's Hierarchy Of Needs } \\
\text { Pyramid model to guide a } \\
\text { society. }\end{array}$ & $\begin{array}{l}\text { This re-evaluates the assumption that } \\
\text { great contributions in a society only } \\
\text { occur in a society's accomplished, } \\
\text { wealthy and powerful citizens. }\end{array}$ \\
\hline $\begin{array}{l}\text { The Economy: We are now } \\
\text { creating the sharing economy, } \\
\text { where everything from cars to } \\
\text { homes to food are being shared. }\end{array}$ & $\begin{array}{l}\text { This challenges the ethic of individual } \\
\text { ownership as a right of every } \\
\text { individual. }\end{array}$ \\
\hline $\begin{array}{l}\text { Charity: We are moving from } \\
\text { "giving back to the less } \\
\text { fortunate" to "paying it } \\
\text { forward". }\end{array}$ & $\begin{array}{l}\text { This challenges the ethical notion that } \\
\text { it is good to have a ruling class, as } \\
\text { long as they give a percentage of their } \\
\text { earnings to the less fortunate. }\end{array}$ \\
\hline $\begin{array}{l}\text { Diet: We are becoming more food } \\
\text { conscious. }\end{array}$ & $\begin{array}{l}\text { This trend is asking major questions } \\
\text { about genetically modified food } \\
\text { (GMO) as well as food deserts (urban } \\
\text { areas where no organic and healthy } \\
\text { food can be found) and the ethical } \\
\text { reasons behind them. }\end{array}$ \\
\hline $\begin{array}{l}\text { The Elderly: We are re-imagining } \\
\text { retirement. }\end{array}$ & $\begin{array}{l}\text { This trend challenges a long held idea } \\
\text { in Western countries that people at a } \\
\text { certain age should retire from society } \\
\text { in favor of younger people. }\end{array}$ \\
\hline
\end{tabular}




\begin{tabular}{|c|c|}
\hline The Trend & The Changing Ethical Position \\
\hline $\begin{array}{l}\text { Big Data: Individuals as well as } \\
\text { private companies are pushing } \\
\text { back against big data. }\end{array}$ & $\begin{array}{l}\text { This trend is causing us to re-think } \\
\text { what privacy is. }\end{array}$ \\
\hline $\begin{array}{l}\text { Family: We are now embracing } \\
\text { the "extensive" family. }\end{array}$ & $\begin{array}{l}\text { This trend is re-defining what we } \\
\text { called "traditional" family structures. }\end{array}$ \\
\hline $\begin{array}{l}\text { Gender: We are embracing the } \\
\text { wisdom, power and } \\
\text { philosophical viewpoint of } \\
\text { women. }\end{array}$ & $\begin{array}{l}\text { This challenges traditional male } \\
\text { dominated concepts of how society is } \\
\text { to function. }\end{array}$ \\
\hline $\begin{array}{l}\text { Integrity: Trust and transparency } \\
\text { are the new currencies. }\end{array}$ & $\begin{array}{l}\text { The open government movements } \\
\text { around the world and transparency } \\
\text { movements by consumer groups are } \\
\text { making keeping secrets a non-starter } \\
\text { in many societies. This movement is } \\
\text { fuelled by the internet. }\end{array}$ \\
\hline $\begin{array}{l}\text { Banks: We are changing our } \\
\text { relationship with banks. }\end{array}$ & $\begin{array}{l}\text { A record number of people around } \\
\text { the world are leaving banks. This will } \\
\text { cause them to rethink some of their } \\
\text { practices. }\end{array}$ \\
\hline $\begin{array}{l}\text { Medicine: The world trend is } \\
\text { toward alternative and } \\
\text { preventative medicine. }\end{array}$ & $\begin{array}{l}\text { This trend will have an impact on } \\
\text { how the current health care system is } \\
\text { organized. }\end{array}$ \\
\hline $\begin{array}{l}\text { Society: We are moving away } \\
\text { from the model of white women } \\
\text { as the world model of beauty. }\end{array}$ & $\begin{array}{l}\text { This development means we are } \\
\text { seeing beauty in a much larger } \\
\text { context. }\end{array}$ \\
\hline $\begin{array}{l}\text { Leadership: We are moving away } \\
\text { from the single leader pyramid to } \\
\text { the lateral leadership model. }\end{array}$ & $\begin{array}{l}\text { The days of one person making all of } \\
\text { the decisions for the many is concept } \\
\text { of the past. }\end{array}$ \\
\hline
\end{tabular}

\section{Businesses are including purpose in their profits}

Businesses throughout the world are realizing the importance of working with a community for a greater social good. At one time, major corporations could trot out their mission statements and ex- 
pected that to pacify those who demanded more accountability from them. Not anymore. The major trend is for them to become more purpose-driven in order to gain the trust of the now wise buyer. Here is an excerpt from The Economist Magazine:

Many businesses are stepping up to a new role, often with partners, to tackle social and economic challenges. Corporations are seeking to build legitimacy - and the license to operate - in the eyes of demanding consumers, employees and stakeholders who care about the impact and motivations of companies with whom they associate. But it's also good business as companies realize mutual benefits with society. Look for more businesses redefining their corporate purpose in this way. ${ }^{1}$

What does this mean to the way we think about our current economic systems?

\section{(a) We are moving away from the leader to leadership}

It seems as though the autocratic authoritarian boss model of the leader has been around forever. We gave these 'bosses' power because we believed they were sent from God. We sometimes surrendered power to them because they gained it at the barrel of a gun. We sometimes forked power over because a crisis occurredwe were afraid and needed someone to be our champion. This still seems quite normal in our everyday world. We've organized our governments, social groups, churches, temples, mosques, and synagogues using this same model because this was how it was done. The way this structure could maintain itself was through control of information. Social media has decimated that strategic advantage of the boss leader. Even more, emerging companies are using the new technologies to create lateral organizations, where participation is becoming an innovative advantage. Here is an excerpt from the magazine Directors and Boards:

Under the old rules of leadership, the idea of building a consensus for action was considered to be

1 Malnight, Thomas. "Global Trends For 2013: A top ten for business leaders." The Economist Magazine, OnlineNovember, 2012, Web 02. 
time-consuming and soft. Consensus was "nice," but it was not something that needed to be achieved. The assumption was that by the definition of leadership, leaders needed to make all the important decisions. Many feared: If the leader was not needed to make all the decisions then why do we need a leader? This attitude was a variation of the theory that the only way to be powerful is to hold all the power for oneself. In reality, this is a sign of failed leadership. ${ }^{2}$

How does this affect all of our social, civic, political and corporate structures?

\section{(b) Connectedness is emerging as a global philosophy}

Ubuntu is a classical African philosophy or world view that focuses on people's allegiances to each other and to humanity. The philosophy is as old as the Bantu ethnic super group, from which many African ethnic groups originated. The core philosophical concept can be summed up in the phrase, "I am because we are; we are because I am." Our greatest success is defined by our connection to others. The more connected we are, the greater the opportunity for success. The less connected we are, the more diminished our success prospects are. Several important books, conferences and writings have emerged over the past few years, signalling the emergence of this philosophy on a world stage. Here is an excerpt from an article in the Journal of Business Ethics:

In our age of globalization, we need a theory of global management consistent with our common human nature. The place to begin in developing such a theory is the philosophy of traditional cultures. The article focuses on the African philosophy (of Ubuntu) and its fruitfulness for contributing to a theory of management consistent with African traditional cultures. It concludes that the needed theory

${ }^{2}$ MacDonald, Bob. "On being a leader: old rules vs. new rules." Directors and Boards 22 September 2005; Web .02 15 December 2013. 
of global management should regard the firm as a community, not a collection of individuals, and should understand the purpose of management as promoting the common good. ${ }^{3}$

What effect would this information have on foreign policy? Our multinational companies? Our knowledge of world affairs?

\section{(c) We are moving into climate change adaptation mode}

For years the ethical debate that involved climate change was about whose data was honest or true. Many nations didn't wait to figure out who would win the argument, they went into climate change adaptation mode. You would think that the first place most nations who go to is the position of its own survival. Yes that is happening, but so is a rigorous effort at looking at the needs of some of the world's most vulnerable citizens. The world's most powerful and emerging members have taken decisive action to help mitigate some of the impact of climate change.

In Southeast Asia, a number of nations are working with their individual farmers who are most at-risk from the affects of climate change. A recent Commonwealth Science and Industrial Research Organization report shared some of the strategies of their member nations:

- Cambodia: investigating supplementary irrigation in lowland rice-based cropping in Svay Rieng Province where there is access to groundwater and some surface irrigation water.

- Laos: changes to water management including supplementary irrigation in lowland rice-based cropping systems of two districts in Savannakhet Province.

- Bangladesh: using data from field trials to refine the cropping systems model APSIM and use the model for im-

3 Lutz, David."African Ubuntu Philosophy and Global Management." Journal of Business Management Ethics. 20 February 2009; Web .02 15 December 2013. 
proved predictions of crop production in relation to locally specific climate, crop variety, soil type and management factors.

- India: improving the delivery of seasonal climate forecasting in Andhra Pradesh to increase agricultural productivity.

The Chinese have decided to pursue a technological approach to climate change. According to the Responding to Climate Change website, the Chinese are pursuing both a mitigation and adaption strategy: The 'Ten Mitigation Technologies are High efficiency super-critical power generation technology, Holistic coal gasificationbased integrated combustion-cycle technology, Non-conventional natural gas exploration and development technology, Large-scale renewable energy power generation, storage and grid connection technology, New energy automobile technology and low carbon fuel substitute technology, City energy supply and end-use energy efficiency and emission reduction technology, Building energy saving technology, Energy saving and scale-up technology of waste energy and waste heat in the production process of iron and steel, metallurgical, chemical and building material industries, Carbon sink technology in agriculture, forestry, husbandry and wetland, and Carbon capture and storage technology.

The Ten Adaptation Technologies include Forecast and prewarning technology of extreme weather events, Drought-ridden region water resource exploration and high-efficiency water utilization, and optimized allocation technology, Drought-resistant and high-temperature-resistant plant species selection and cultivation, and pest-prevention and control technology, Typical climatesensitive ecosystem protection and remediation technology, Climate change impact and risk assessment technology, Human health integrated adaptation technology, Typical coastal land adaptation technology, City lifeline engineering safety guarantee technology in response to extreme weather events, Standards and regulation amendment of some key sectors in adaptation to climate change, and Human-controlled weather manipulation technology

A new report by the Inter-American Development Bank identified these points as strategies for Latin America in climate change adaptation: (i) Assist countries in the region on their efforts towards a 
Climate resilient and carbon neutral economy, (ii) Strengthen/build local institutional capacity to identify and assess vulnerability to climate change, (iii) Provide finance and technical assistance in the design and implementation of strategic and replicable pilots of adaptation measures, (iv) Promote preventive risk management and risk reduction strategies, including risk sharing and innovative transfer mechanisms, and (v) Assist countries in the development and assessment of key policy and regulatory instruments.

We can be honest here and note that the reason why this discussion is noteworthy is because the old paradigm produced an "every man for himself" or more accurately "every nation for itself" ethical approach to world affairs. Certainly the world's nations have responded to dramatic crises over the years, but this level of anticipation of a disaster is unprecedented in the history of humanity. Our ethical view of how we take care of others has expanded. What can this mean for how we see other cultures? How does it dismantle stereotypes we've created around the cultural "other".

\section{(d) We are sharing}

In the old paradigm, people "owned" things, like cars, homes (even though we technically didn't really own them - the bank did), and even other people (slavery). This was part of the concept that one's personal value came from his accumulation of things. As more and more people rethink the staggering and unsustainable finance models on high-ticket items, sharing seems more reasonable.

Here's what's being said: "To rent or own, that is the question posed by the burgeoning sharing economy. For a growing population engaged in this high-tech, low-cost 'collaborative economy,' access to cars, clothes, cuisine - or even a cat - is better than ownership." ${ }^{4}$ How does this information reshape our consumerism going forward? How does it change our goals, our patterns and our lives?

4 Gramick, Jeannine. "As more take the spiritual route, religions decline."National Catholic Reporter Online 8th August 2012; Web .02 16 December 2013. 


\section{(e) We are moving from religious to spiritual}

As with many institutions of the old paradigm, religions are also going through profound structural transformation. The quote below from the National Catholic Reporter sums up what's happening in the world today:

Polls show that the public generally sees religion as a system promoting beliefs about God, instead of advocating faith in God or love of God. People today want to belong to a community that is more interested in spiritual values and practices than in believing doctrines that seem meaningless and unconnected to their lives. They want contact with the sacred without the intermediary of an institutional or doctrinal structure. Dogma, the "spiritual" generation says, is on life support and the plug needs to be pulled.5

How would this knowledge affect the way religious leaders see younger people and the way they approach life? We are moving away from the "self made man or woman" toward collective cooperation. The enduring myth of how humankind started to flourish in the world is based squarely in Darwinian Theory. It also served as a way some could subjugate others with justification, claiming it is the way of life. Truth is, the rugged individual - every person for themselves idea is fairly recent in the history of humanity. While it may have worked for a few over a limited period of time, it is not a sustainable method. Some scientists would even suggest that our very survival as a species may depend on our ability to let go of the false nature of rugged individualism. Here is an excerpt from Discovery magazine: "Cooperation leads to intelligence. In fact, researchers believe intelligence, in this case, correlated with the size of a brain's neural network, in our species and others may have

5 Gramick, Jeannine. "As more take the spiritual route, religions decline." National Catholic Reporter Online 8th August 2012; Web .02 16 December 2013. 
been an adaption for tool use, for social learning, and for the accumulation of culture." 6

How would this new understanding effect the way that we design local community policy that promotes partnerships rather than single contractors? Here is what seems apparent from this data. (i) There is a dramatic social-spiritual paradigm shift happening at this time. (ii) This shift is driven by verifiable trends. (iii) These trends are leading us to rethink commonly held ideas or conventional wisdom. (iv) This change of how we look at conventional wisdom is also causing us to rethink our ethical approaches to our human experience. (v) We cannot talk about a new approach to ethics without first considering the context of the paradigm shift.

With these things in mind, I suggest a more comprehensive approach to the new ethics environment that is on the horizon. This approach involves the following:

\section{A closer look at the new paradigm}

The ethics conversations that we are having now did not occur in a vacuum. They existed for years in a world that supported them. To lose sight of their environment is to lose sight of how they came to be. The new paradigm that correlates with our shifting ethical position is unique in the history of humanity. While shifting ethical positions because of increased knowledge is a part of humanity's journey, the current rush of shifting ideas pointing in thedirection of a more egalitarian and compassionate world is special. Before we rush to find an ethical position on something that has changed, we may want to wait for the dust to settle. The new world is still emerging.

We should recognize the tremendous world we are moving into. The trends of the new paradigm shift are more inclusive, more cooperative, more forgiving, more generous, and more connected than the ethics of the old paradigm. This means our ethical posi-

6 Viegas, Jennifer. "Cooperation Is A Key To Intelligence." Discovery News, 10 April 2012; Web. 0216 December 2013. 
tions should also be more inclusive, cooperative, forgiving, generous and connected. We should look at the changes collectively and recognize we may be witnessing something entirely different from the gradual change of ethical positions over an extended time.

In the old paradigm, ethical positions were provided so that we could create uniform law and policy so that we did the "right thing" according to societal norms. In the new paradigm, ethical positions are moving from rules outside of us to obey, to a filter in which we process the daily world around us. The way we view ethics will become more personal.

These kinds of shifts happening in society today are not blips on the screen, but long term trends that have been building for years. We are now living in the time to get out in front of these trends to set ethical approaches and policy so that the transitions are smoother and more directed. As with all shifts in society, old ideas die hard. There will be those who will want to return to ideas and ethical approaches simply because we always have. They may have a vested interest in maintaining the status quo. However, advocating for new ethical tools in a changing world is simply helping to facilitate away of being in the face of inevitable transition. The sooner we are able to step into that role, the better.

\section{References}

Malnight, Thomas. "Global trends for 2013: A top ten for business leaders." The Economist Magazine, Online, 15 November 2012; Web. 02, 15 December 2013.

MacDonald, Bob. "On being a leader: Old rules vs. new rules." Directors and Boards, 22 September 2005; Web.02, 15 December 2013.

Lutz, David. "African Ubuntu philosophy and global management." Journal of Business Management Ethics. 20 February 2009; Web.02, 15 December 2013.

Zimmerman, Eiline. "Rent or own? The new sharing economy values access over ownership." The Christian Science Monitor; Web. 02, 30 September 2012.

Gramick, Jeannine. "As more take the spiritual route, religions decline." National Catholic Reporter Online, 8th August 2012; Web.02, 16 December 2013.

Viegas, Jennifer. "Cooperation is a key to intelligence," Discovery News, 10 April 2012; Web. 02, 16 December 2013. 